九州大学学術情報リポジトリ

Kyushu University Institutional Repository

\title{
Laboratory Study for the Phytoremediation of Eutrophic Coastal Sediment Using Benthic Microalgae and Light Emitting Diode (LED)
}

Kwon, Hyeong Kyu

Department of Oceanography, Pukyong National University

Oh, Seok Jin

Department of Oceanography, Pukyong National University

Yang, Han-Soeb

Department of Oceanography, Pukyong National University

Kim, Dong-Myung

Department of Ecological Engineering, Pukyong National University

他

https://doi.org/10.5109/27374

出版情報：九州大学大学院農学研究院紀要. 58 (2)，pp.417-425，2013-09. Faculty of Agriculture， Kyushu University

バージョン：

権利関係: 


\title{
Laboratory Study for the Phytoremediation of Eutrophic Coastal Sediment Using Benthic Microalgae and Light Emitting Diode (LED)
}

\author{
Hyeong Kyu KWON ${ }^{1}$, Seok Jin OH ${ }^{1 *}$, Han-Soeb YANG ${ }^{1}$, Dong-Myung KIM ${ }^{2}$, \\ Ik Joon KANG ${ }^{3}$ and Yuji OSHIMA
}

\author{
Laboratory of Marine Environment Science, Division of Animal \& Marine Bioresource Sciences, \\ Department of Bioresource Sciences, Faculty of Agriculture, Kyushu University, \\ Fukuoka 812-8581, Japan \\ (Received April 26, 2013 and accepted May 9, 2013)
}

\begin{abstract}
We investigated the effects of three wavelengths of light (blue; $450 \mathrm{~nm}$, yellow; $590 \mathrm{~nm}$ and red; $650 \mathrm{~nm}$ ) using light emitting diodes (LEDs) on the growth of benthic microalgae (BMA) Achnanthes sp., Amphora sp., Navicula sp., Nitzschia sp. and the harmful algae Alexandrium tamarense. In addition, we confirmed phytoremediation possibilities of eutrophic coastal sediments obtain from Masan Bay in $60 \mathrm{~L}$ water tank with LEDs. The growth rates of four BMA species could grow under all irradiance conditions of three wavelengths. However, the growth rate of $A$. tamarense was stimulated under blue LED and suppressed under yellow and red LED to less than $70 \mu \mathrm{mol} / \mathrm{m}^{2} / \mathrm{s}$. In water tank experiments with no light, environmental factors, such as cell density of Nitzschia sp., chlorophyll $a$ (Chl. a), chemical oxygen demand (COD), acid volatile sulfide (AVS), dissolved inorganic nitrogen (DIN) and dissolved inorganic phosphorus (DIP), were no significant increases or decreases. However, in water tank experiments with LED, cell density of Nitzschia sp. and chl. $a$ increased, whereas DIN, DIP, and AVS levels decreased. The removal efficiencies for DIN, DIP, and AVS were high in the order of blue LED, fluorescent lamp, red LED, and yellow LED. Thus, in order to remediate eutrophic sediments, red LED may be the most appropriate during the spring and summer when appearances of harmful algae in the genus Alexandrium are present and blue LED may be the most appropriate during other seasons.
\end{abstract}

Key words: benthic microalgae, eutrophic sediment, light emitting diode, phytoremediation, wavelength

\section{INTRODUCTION}

For many years, most enclosed coastal areas of Korea, especially in the southern sea, has been the recipient of various environmental damages because of rapid growth in urban and industrial development. As a result, the area system has become heavily polluted by a variety of wastes, including untreated municipal sewage and industrial wastewater. These contaminants have caused harmful algal blooms, sharp oxygen depletion, loss of aquatic life, and aesthetic problems (Lee and Min, 1990; Yoo, 1991; Yim et al., 2005). Since the 1980s, there pollution problems have generated both public and regulatory concerns. In case of Masan Bay, where is a representative eutrophic area of Korea, a wastewater treatment plants potentially treated about $50 \%$ of the total freshwater input into bay is constructed by designated as special management area in 1982 (Cho et al., 2000; MLTM, 2008). Moreover, intensive dredging of polluted sediments was also conducted from 1990 to 1994 (Lee and Min, 1990). However, water quality in Mansa Bay has not improved substantially despite these efforts. To solve pollutant problems in Masan Bay, total pollutant load management system (TPLMS) was implemented in

\footnotetext{
Department of Oceanography, Pukyong National University, Busan 608-737, Korea

2 Department of Ecological Engineering, Pukyong National University, Busan 608-737, Korea

3 Open problem study program, Faculty of Agriculture, Kyushu University, Hakozaki, Fukuoka 812-8581, Japan

* Corresponding author (E-mail: sjoh1972@pknu.ac.kr)
}

2007. The TPLMS accounts for the current water quality status and assimilative capacity of the water body by the TPLMS in two-tiers: management of chemical demand oxygen (COD) from 2007 to 2011 and management of total nitrogen (TN) and total phosphorus (TP) from 2012 to 2016 (MLTM, 2008).

Although decreasing the amount of nutrient loading to the bay from urban runoff is important, the control of nutrients in eutrophic sediments might also help reduce TN and TP concentrations in seawater. To remediate the eutrophic sediment, physical methods (dredging and aeration), chemical methods (additional yellow loess, slag and oyster shell) and biological methods (microbial activity) have been used (Murphy and Prepas, 1990; Karim et al., 2003; Yamamoto et al., 2008; Asaoka and Yamamoto, 2010).

Dredging is considered one of the most practical methods for remediating enclosed eutrophic bay. Dredging is advantageous because it can have rapid remediation effects. However, dredging can be expensive and can cause secondary problems such as the diffusion of silt, treatment of dredged sediment and the huge budget. Therefore, the development of more ecofriendly and cost effective remediation methods would be necessary.

The term "phytoremediation" describes the process of contaminant degradation in the environment by biological methods using the metabolic potential of microorganisms to degrade a wide variety of organic compounds (Wolfe et al., 1996; Romantschuk et al., 2002; Suresh and Ravishankar, 2004). The main advantage of 
phytoremediation is relatively low cost methods, sustainable methods and non-invasive technique, leaving the ecosystem intact compared to civil engineering methods. Recently, a number of studies have been conducted to assess the potential of phytoremediation for the recovery of impacted ecosystems (Bragg et al., 1994; Coates et al., 1998; Lovley, 2001; Suzuki et al., 2002). These studies suggested that phytoremediation could be a useful technique for remediating contaminated marine environments.

Oh et al. (2007) and Kwon et al. (2013) proposed the phytoremediation using benthic microalgae (BMA) and light emitting diodes (LEDs). If the wavelength of light, which BMA could grow but not harmful algae, is able to illuminate on the eutrophic coastal sediments with no light due to high suspended solid, BMA may be able to remediate because of oxygen production and nutrient uptake due to photosynthetic activity. In this study, we investigated the effects of monochromatic light from LEDs on the growth of the BMA and harmful algae. In addition, we confirmed the phytoremediation possibilities of eutrophic coastal sediments obtain from Masan Bay in $60 \mathrm{~L}$ water tank with LED.

\section{MATERIALS AND METHODS}

\section{Strains and culture conditions}

BMA Achnanthes sp., Amphora sp., Navicula sp., Nitzschia sp. and the harmful algae Alexandrium tamarense were isolated from surface sediment and water of Masan Bay in Korea (N35 $7^{\prime} 17^{\prime \prime}$, E128 $36^{\prime} 01^{\prime \prime}$ ), in April 2010. The isolates were rinsed repeatedly in sterile seawater during the logarithmic growth phase, and were treated with an antibiotic mixture AM 9 for axenic cultures (Porter and Feig, 1980). Stock cultures were maintained in f/2 medium based on seawater of East Sea (N36 $24^{\prime} 94^{\prime \prime}$, E130 $42^{\prime} 06^{\prime \prime}$ ) (Guillard and Ryther, 1962), and containing $0.001 \mu \mathrm{M}$ selenium (as $\mathrm{H}_{2} \mathrm{SeO}_{3}$ ) as suggested by Doblin et al. (1999). A. tamarense was cultured in medium enriched without silicate. All media were adjusted to $\mathrm{pH} 8.2$ using $\mathrm{HCl}$ or $\mathrm{NaOH}$, and were sterilized by membrane filter (Sterivex-GS, $0.22 \mu \mathrm{m}$ filter, Millipore, USA). Temperature, salinity, and light conditions for stock cultures and all experiments were $20^{\circ} \mathrm{C}, 30 \mathrm{psu}$, and $100 \mu \mathrm{mol} / \mathrm{m}^{2} / \mathrm{s}$ (measured with QSL-2101, Biospherical Instruments, USA) under cool-white fluorescent lamps with an illumination cycle of $12 \mathrm{~h}$ : $12 \mathrm{~h}$ light/dark cycle. Prior to the experiments, all equipment and glassware were treated with approximately $30 \% \mathrm{HCl}$, and then thoroughly rinsed with distilled water and autoclaved at $202 \mathrm{kPa}$ for $20 \mathrm{~min}$.

\section{Wavelength and irradiance experiments}

To assess the effects of monochromatic light on growth, we used four wavelengths of light (blue LED; $450 \mathrm{~nm}$, yellow LED; $590 \mathrm{~nm}$, red LED; $650 \mathrm{~nm}$ and cool-white fluorescent lamp; mixed wavelength). Four species of BMA and $A$. tamarense were inoculated to an initial cell density of approximately $1 \times 10^{2}$ cells $/ \mathrm{ml}$. The irradiance of each wavelength was 10, 30, 50, 70, 100,
150, 300 and $400 \mu \mathrm{mol} / \mathrm{m}^{2} / \mathrm{s}$ (measured with a QSL2100; Biospherical Instruments Inc., San Diego, CA, USA) on a 12h : 12h light/dark cycle. Daily, at 10:00 AM, in vivo fluorescence was measured using a fluorometer (model 10-100R; Turner Designs, Mountain View, CA, USA). All measurements were conducted in triplicate. Some data that showed significantly different trends from the other two were excluded from calculations. Specific growth rate ( $\mu$ : /day) was calculated using a least square regression of log-transformed in vivo fluorescence data during the exponential growth phase. The specific growth rate was determined using the following formula:

$$
\mu=\frac{1}{\Delta t} \ln \frac{N_{t}}{N_{0}}
$$

where $N_{0}$ and $N_{t}$ are the initial and final in vivo fluorescence values of the exponential period and $\Delta t$ is the period of exponential growth phase.

As there was no apparent photoinhibiton at the irradiance levels used, a rectangular hyperbolic curve was fitted for the relationship between specific growth rate and irradiance (Lederman and Tett, 1981)

$$
\mu=\mu_{\max } \frac{I-I_{0}}{\left(K_{I}+I_{0}\right)+\left(I-I_{0}\right)}
$$

where $\mu_{\text {max }}$ is the maximum specific growth rate (/day), $I$ is the irradiance $\left(\mu \mathrm{mol} / \mathrm{m}^{2} / \mathrm{s}\right), I_{0}$ is the compensation photon flux density $\left(\mu \mathrm{mol} / \mathrm{m}^{2} / \mathrm{s}\right)$ and $K_{I}$ is the irradiance at $\mu_{\max } / 2$ (half-saturation light intensity).

Generally, the specific growth rate increased with increasing irradiance up to an optimum or saturating light intensity. However, the specific growth rate of some microalgae decreased rapidly with increases in irradiance because of photoinhibition. In this case, we estimated the relationship between the growth rates and light intensity using Eq. (3) proposed by Steele (1962):

$$
\mu=\mu_{\max } \frac{I}{I_{\text {opt }}} \exp \left(1-\frac{I}{I_{0}}\right)
$$

where $\mu_{\max }$ is the maximum specific growth rate (/day), $I$ is the irradiance $\left(\mu \mathrm{mol} / \mathrm{m}^{2} / \mathrm{s}\right)$ and $I_{\text {opt }}$ is the optimum photon flux density $\left(\mu \mathrm{mol} / \mathrm{m}^{2} / \mathrm{s}\right)$.

Eq. (3) was used when the specific growth rate decreased exponentially after photoinhibition. If the specific growth rate is decreased linearly, Eq. (3) was difficult to use. Thus, we estimated the relationship between the growth rates and light intensity using Eq. (4) proposed by Oh et al. (2007):

$$
\mu=\alpha \times \exp \left(-\frac{1}{\beta}\right)-\alpha+\delta \times I
$$

where $\mu$ is the specific growth rate (/day), $\alpha, \beta$ and $\delta$ are constant. $I_{\text {opt }}$ and $\mu_{\text {max }}$ can be calculated from Eq. (5) and Eq. (6), respectively

$$
\begin{aligned}
& I_{\text {opt }}=-\beta \times \ln \left(\frac{\beta \delta}{\alpha}\right) \\
& \mu_{\max }=\beta \delta-\alpha-\delta \beta \times \ln \left(\frac{\beta \delta}{\alpha}\right)
\end{aligned}
$$




\section{Net photosynthesis rate of BMAs}

The net photosynthesis rate (NPR) of BMA was measured by the "light and dark bottle" oxygen method. $50 \mathrm{ml}$ oxygen bottles were filled with an aliquot of culture containing approximately $3 \times 10^{3}$ cells $/ \mathrm{ml}$ of BMA. Initial oxygen concentrations were adjusted to less than $2 \mathrm{mg} / \mathrm{L}$ using nitrogen gas. Then, oxygen bottles were incubated for $24 \mathrm{~h}$ under each wavelength (blue LED; $450 \mathrm{~nm}$, yellow LED; $590 \mathrm{~nm}$, red LED; $650 \mathrm{~nm}$ and coolwhite fluorescent lamp; mixed wavelength) at $70 \mu \mathrm{mol} /$ $\mathrm{m}^{2} / \mathrm{s}$. After the incubation period, evaluated oxygen concentrations were determined by the Winkler method (Winkler, 1888). All measurements were conducted in quintuplicate. Data that showed significantly different trends from the other replicates were excluded from calculations. The NPR was calculated as $\mathrm{O}_{2} \mathrm{ng} / \mathrm{cell} / \mathrm{h}$.

\section{Water tank experiments using BMA and LEDs}

The $60 \mathrm{~L}$ water tank experiments were conducted in order to assess the phytoremediation of eutrophic sediments using LEDs before field application experiment. BMA species was used Nizschia sp., which is a useful species for phytoremediation (Kwon et al., 2013). Nitzschia sp. (ca. $1 \times 10^{3}$ cells $/ \mathrm{cm}^{2}$ ) was replanted on the water tank filled with sediment (ca. $20 \mathrm{~kg}$ ) and bottom water (ca. $20 \mathrm{~L}$ ) collected from Masan Bay. To remove other biological effects, the sediment and bottom water were autoclaved at $202 \mathrm{kPa}$ for $20 \mathrm{~min}$ and sterilized by membrane filter (Sterivex-GS, $0.22 \mu \mathrm{m}$ filter, Millipore, USA), respectively. Light sources were irradiated with cool-white fluorescent lamp (mixed wavelength), blue LED (450 nm), yellow LED (590 nm) and red LED (650 nm) under light intensity of $70 \mu \mathrm{mol} / \mathrm{m}^{2} / \mathrm{s}$. The control tank did not irradiated with light. At intervals of two days, sediment samples were collected using acrylic tube (diameter; $4 \mathrm{~cm}$ ) from the water tank. Cell density of Nitzschia sp. was counted under microscope (TE 2000, Nikon, Japan) and chlorophyll $a$ (chl. $a$ ) was measured acetone extraction as suggested by Scor-Unesco (1966). Acid-volatile sulfide (AVS) was determined in duplicate subsamples (ca. $1 \mathrm{~g}$ ) using a $\mathrm{H}_{2} \mathrm{~S}$-absorbent column (GASTEC, Kanagawa, Japan). Chemical oxygen demand (COD) was determined according to the Korean standard methods for analysis of marine environment samples (MLTM, 2010). Dissolved inorganic nutrient (DIN; $\left.\mathrm{NH}_{4}{ }^{+}-\mathrm{N}+\mathrm{NO}_{2}^{-}-\mathrm{N}+\mathrm{NO}_{3}{ }^{-}-\mathrm{N}, \mathrm{DIP}\right)$ in the interstitial water was measured by method of Strickland and Parsons (1972) after centrifugation (3000 rpm, $15 \mathrm{~min}$ ) of the sediment.

Removal flux $(R F)$ of nutrients was determined using the following formula:

$$
R F=\frac{\left(C_{I}-C_{F}\right) \times V}{T \times A}
$$

where $R F$ is the removal flux of the nutrient ( $\mathrm{mg} \mathrm{N} / \mathrm{m}^{2} /$ day or $\mathrm{mg} \mathrm{P} / \mathrm{m}^{2} /$ day), $C_{I}$ and $C_{F}$ is the initial and final concentrations of the nutrient $(\mu \mathrm{M}), V$ is the volume of collected sediment in water tank $\left(\mathrm{m}^{3}\right), T$ is the duration of the experiment (day) and $A$ is the surface area of the sediment $\left(\mathrm{m}^{2}\right)$.

Table 1. The parameter of four benthic microalgae species and harmful algae Alexandrium tamarense as a function of light intensity under different wavelengths

\begin{tabular}{|c|c|c|c|c|c|}
\hline Species & Wavelength & Hyperbolic equation & $\mu_{\max }$ (/day) & $I_{0}\left(\mu \mathrm{mol} / \mathrm{m}^{2} / \mathrm{s}\right)$ & $I_{o p t}\left(\mu \mathrm{mol} / \mathrm{m}^{2} / \mathrm{s}\right)$ \\
\hline \multirow[t]{4}{*}{ Achnanthes sp. } & Fluorescent lamp & $\mu=0.61(I-7.85) /(I+40.10)$ & 0.61 & 7.85 & - \\
\hline & Blue LED & $\mu=0.79(I-6.65) /(I+49.07)$ & 0.79 & 6.65 & - \\
\hline & Yellow LED & $\mu=0.40(I-6.10) /(I+74.35)$ & 0.40 & 6.10 & - \\
\hline & Red LED & $\mu=0.56(I-4.39) /(I+95.78)$ & 0.56 & 4.39 & - \\
\hline \multirow[t]{4}{*}{ Amphora sp. } & Fluorescent lamp & $\mu=0.52(I-3.69) /(I+18.09)$ & 0.52 & 3.69 & - \\
\hline & Blue LED & $\mu=0.78(I-6.91) /(I+57.44)$ & 0.78 & 6.91 & - \\
\hline & Yellow LED & $\mu=0.34(I-4.08) /(I+98.29)$ & 0.34 & 4.08 & - \\
\hline & Red LED & $\mu=0.45(I-3.06) /(I+97.94)$ & 0.45 & 3.06 & - \\
\hline \multirow[t]{4}{*}{ Navicula sp. } & Fluorescent lamp & $\mu=-0.61 \exp (\mathrm{I}-\mathrm{I} / 12.17)+0.67-0.0003 \mathrm{I}$ & 0.64 & - & 62.6 \\
\hline & Blue LED & $\mu=-0.93 \exp (\mathrm{I}-I / 18.86)+0.60-0.0009 \mathrm{I}$ & 0.85 & - & 75.9 \\
\hline & Yellow LED & $\mu=0.48(I-3.11) /(I+51.10)$ & 0.48 & 3.11 & - \\
\hline & Red LED & $\mu=0.56(I-3.75) /(I+73.88)$ & 0.56 & 3.75 & - \\
\hline \multirow[t]{4}{*}{ NItzschia sp. } & Fluorescent lamp & $\mu=0.50(I-7.96) /(I+35.55)$ & 0.50 & 7.96 & - \\
\hline & Blue LED & $\mu=0.77(I-3.06) /(I+65.62)$ & 0.77 & 3.06 & - \\
\hline & Yellow LED & $\mu=0.36(I-5.63) /(I+60.58)$ & 0.36 & 5.63 & - \\
\hline & Red LED & $\mu=0.43(I-4.65) /(I+101.2)$ & 0.43 & 4.65 & - \\
\hline Alexandrium & Fluorescent lamp & $\mu=0.52(I-39.12) /(I+33.54)$ & 0.52 & 49.1 & - \\
\hline \multirow[t]{3}{*}{ tamarense } & Blue LED & $\mu=0.83(I-7.79) /(I+61.33)$ & 0.83 & 7.79 & - \\
\hline & Yellow LED & $\mu=0.30(I-72.67) /(I+109.8)$ & 0.30 & 72.7 & - \\
\hline & Red LED & $\mu=0.48(I-82.17) /(I+86.80)$ & 0.48 & 82.2 & - \\
\hline
\end{tabular}



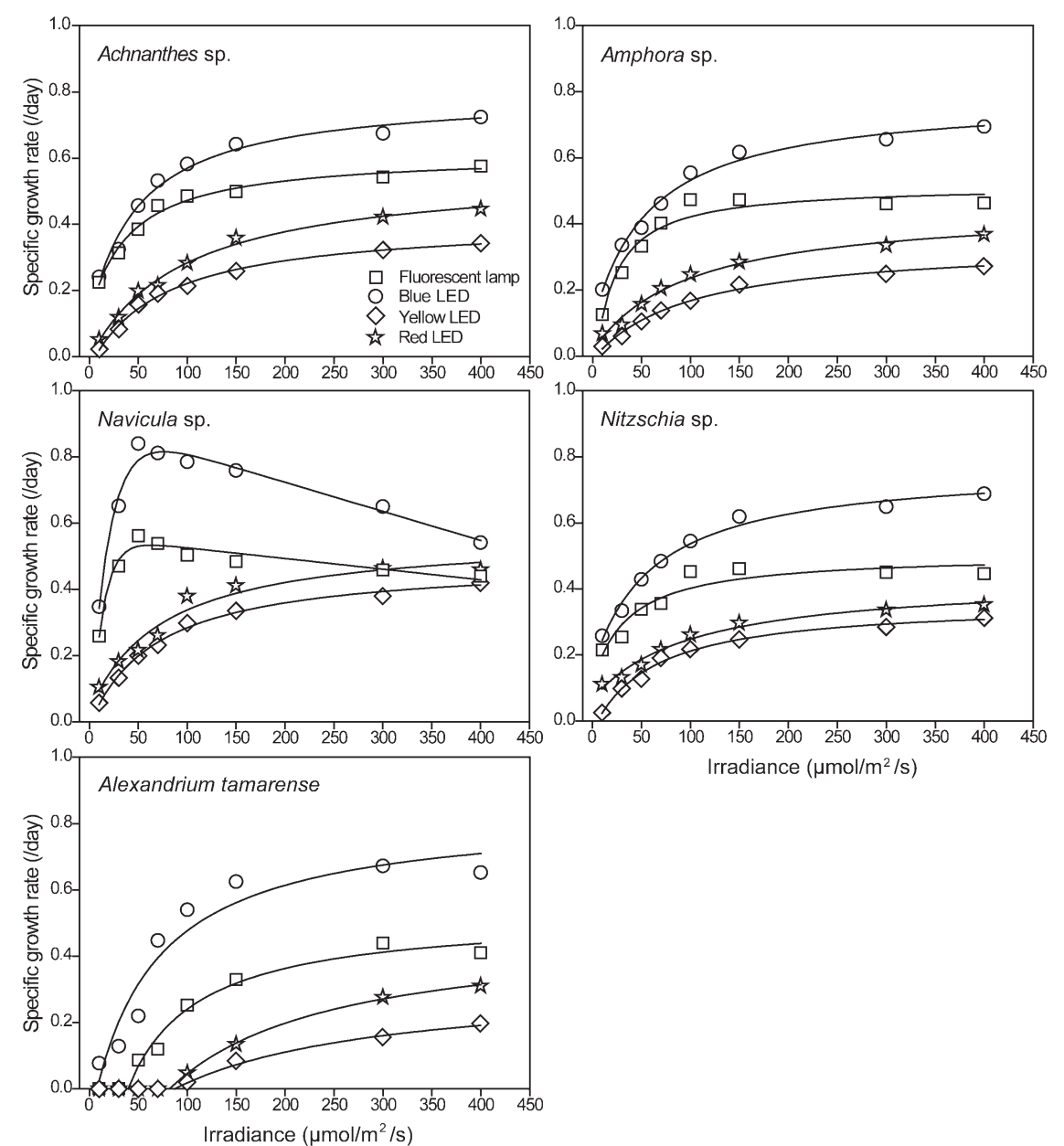

Fig. 1. Specific growth rate of benthic microalgae Achnanthes sp., Amphora sp., Navicula sp., Nitzschia sp. and harmful algae Alexandrium tamarense as a function of light intensity of blue LED (450 nm), yellow LED $(590 \mathrm{~nm})$, red LED $(650 \mathrm{~nm})$ and fluorescent lamp (mixed wavelength).
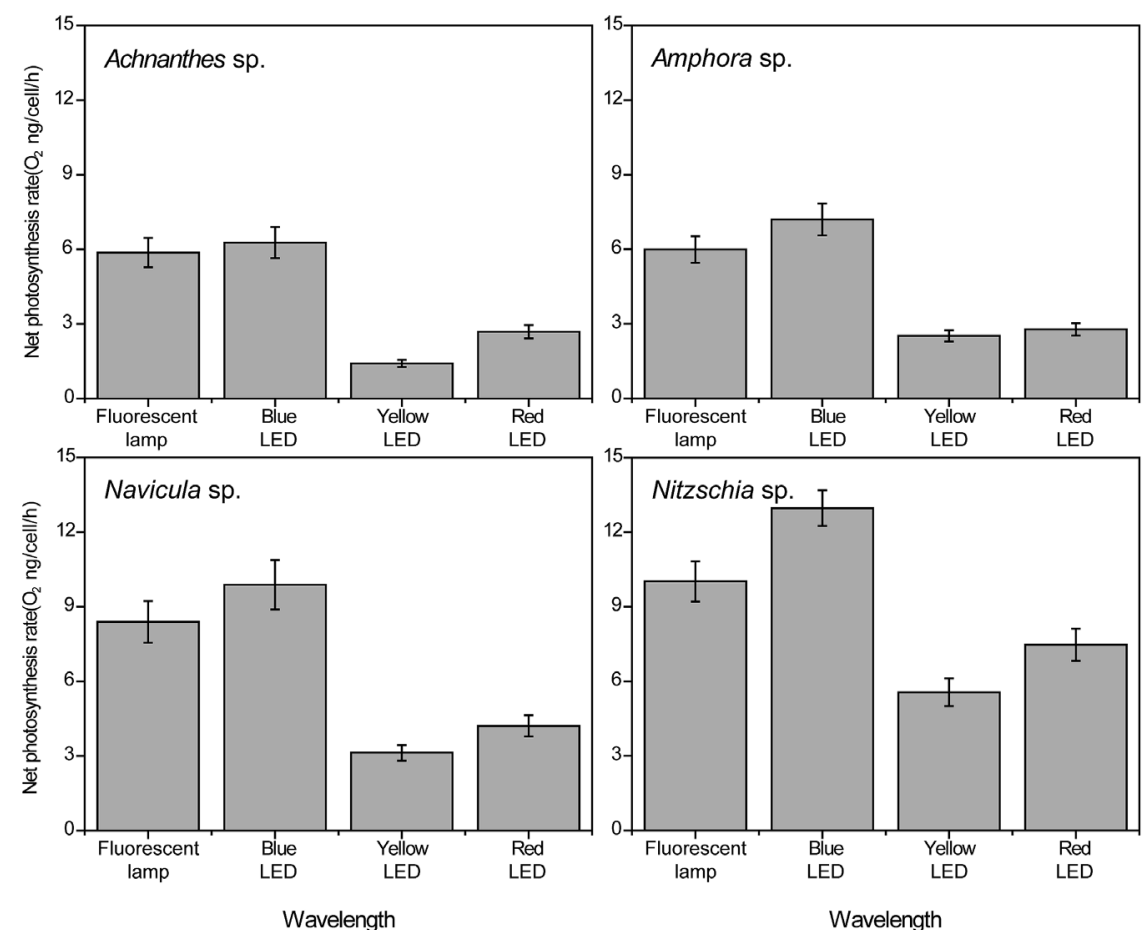

Fig. 2. Net photosynthesis rate of benthic microalgae Achnanthes sp., Amphora sp., Navicula sp., Nitzschia sp. under blue LED (450 nm), yellow LED $(590 \mathrm{~nm})$, red LED $(650 \mathrm{~nm})$ and fluorescent lamp (mixed wavelength). 

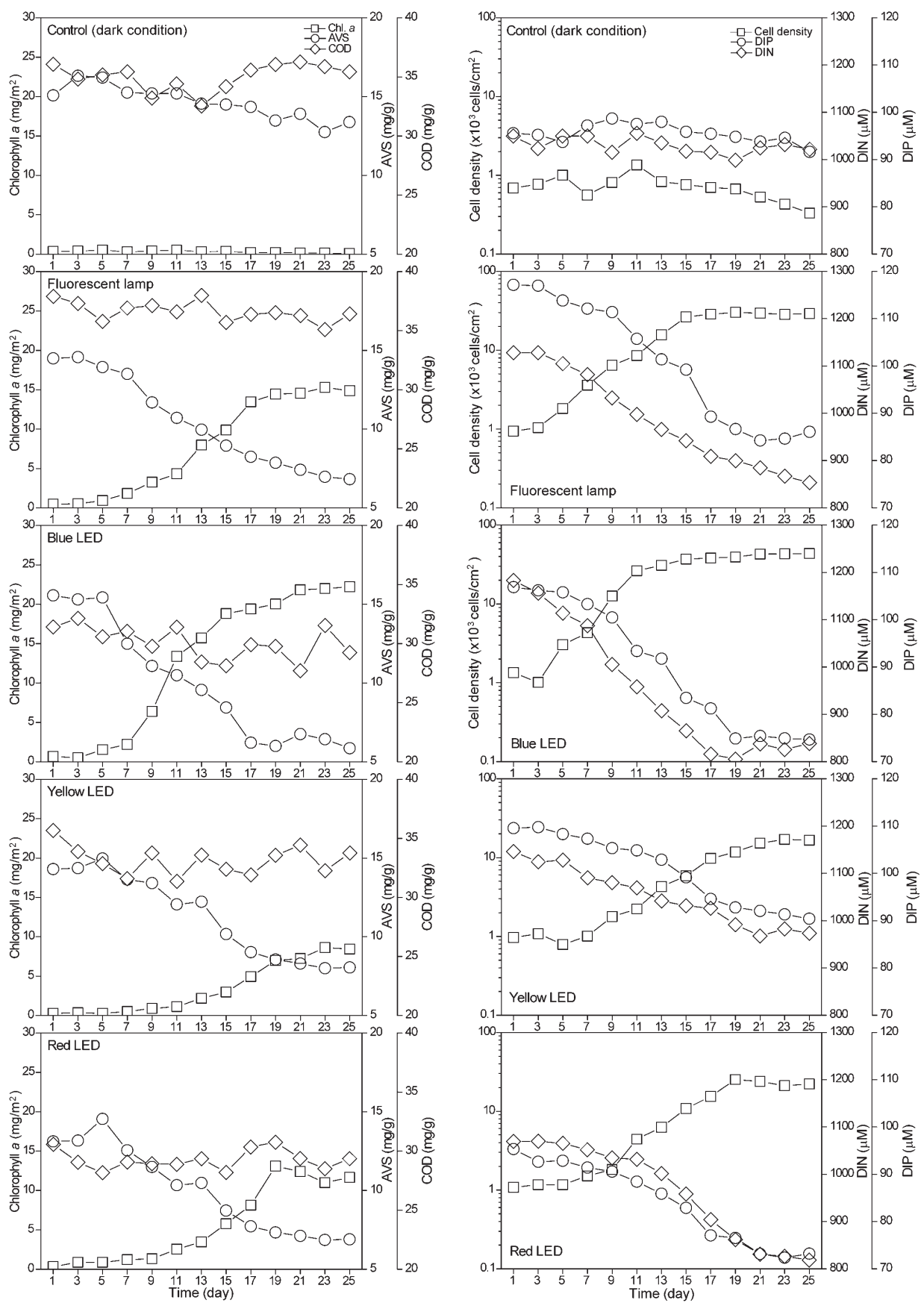

Fig. 3. The changes of chl. $a$, cell density of Nitzschia sp., AVS, COD, DIN and DIP under blue LED $(450 \mathrm{~nm})$, yellow LED (590 nm), red LED (650 nm) and fluorescent lamp (mixed wavelength).

Table 2. Specific growth rate of Nitzschia sp. and removal flux under different wavelengths in the 60L water tank

\begin{tabular}{cccc}
\hline \multirow{2}{*}{ Wavelength } & \multirow{2}{*}{$\begin{array}{c}\text { Specific } \\
\text { growth rate } \\
\text { (/day) }\end{array}$} & $\begin{array}{c}\text { Removal flux } \\
\text { (mg N/m²/day) }\end{array}$ & $\begin{array}{c}\text { DIP } \\
\left(\mathrm{mg} \mathrm{P}^{2} / \mathrm{m}^{2} / \text { day }\right)\end{array}$ \\
\hline Fluorescent lamp & 0.25 & 1.51 & 0.19 \\
Blue LED & 0.32 & 1.63 & 0.25 \\
Yellow LED & 0.14 & 1.03 & 0.10 \\
Red LED & 0.18 & 1.19 & 0.13
\end{tabular}

RESULTS

Effects of monochromatic light on the growth of four BMA species and $A$. tamarense

The growth rates of four BMA species generally increased with increasing irradiance under fluorescent lamp, blue LED, yellow LED and red LED (Fig. 1). However, photoinhibition was observed with Navicula sp. under fluorescent lamp and blue LED at more than $50 \mu \mathrm{mol} / \mathrm{m}^{2} / \mathrm{s}$ (Fig. 1). For the harmful algae A. tamarense, the growth rate increased with increasing irradiance under blue LED, but was not grew under fluorescent lamp at irradiance levels less than $30 \mu \mathrm{mol} / \mathrm{m}^{2} / \mathrm{s}$ 
and yellow and red LED at irradiance levels less than $70 \mu \mathrm{mol} / \mathrm{m}^{2} / \mathrm{s}$. The derived parameters by irradiancegrowth curves are given in Table 1 . The $\mu_{\max }$ of four BMA species and A. tamarense were high in the order of blue LED, fluorescent lamp, red LED, yellow LED. The $I_{0}$ of four BMA species was less than $10 \mu \mathrm{mol} / \mathrm{m}^{2} / \mathrm{s}$ under all wavelengths. For $A$. tamarense, $I_{0}$ was similar to BMA under blue LED as $7.79 \mu \mathrm{mol} / \mathrm{m}^{2} / \mathrm{s}$, whereas the $I_{0}$ was much high under fluorescent lamp, yellow LED and red LED as 49.1, 72.7 and $82.2 \mu \mathrm{mol} / \mathrm{m}^{2} / \mathrm{s}$, respectively.

\section{Net photosynthesis rate of four BMA species under different wavelengths}

The NPR for Achnanthes sp. were 5.87, 6.27, 1.41 and $2.69 \mathrm{ng} \mathrm{O}_{2} /$ cell/h under fluorescent lamp, blue LED, yellow LED and red LED, respectively (Fig. 2). For Amphora sp., the NPR were 5.99, 7.20, 2.52 and $2.78 \mathrm{ng}$ $\mathrm{O}_{2} /$ cell/h, respectively (Fig. 2). For Navicula sp., the NPR were 8.39, 9.88, 3.13 and $4.21 \mathrm{ng} \mathrm{O}_{2} /$ cell/h under fluorescent lamp, blue, yellow and red LED, respectively (Fig. 2). Finally, for Nitzschia sp., the NPR were 10.02, 12.97, 5.56 and $7.47 \mathrm{ng} \mathrm{O}_{2} /$ cell/h, respectively (Fig. 2). The NPR of BMA was high in the order of blue LED, fluorescent lamp, red LED, yellow LED. In addition, among the four BMA species, Nitzschia sp. was the highest NPR under all wavelengths.

\section{L water tank experiments using BMA (Nitzschia sp.) and LEDs}

In the control experiment (dark condition), there were no significant increases or decreases in the environmental factors (Fig. 3). However, in the experimental groups, cell density of Nitzschia sp. and chl. a increased and inorganic nutrients and AVS decreased during experiment period (Fig. 3). Under fluorescent lamp, chl. $a$ increased from 0.48 to $15.46 \mathrm{mg} / \mathrm{m}^{2}$ and cell density of Nitzschia sp. increased by $3 \times 10^{4} \mathrm{cell} / \mathrm{cm}^{2}$. AVS decreased from 14.57 to $6.83 \mathrm{mg} \mathrm{S} / \mathrm{g}-\mathrm{dry}$. In addition, DIN and DIP decreased from 1271 to $942 \mu \mathrm{M}$ and

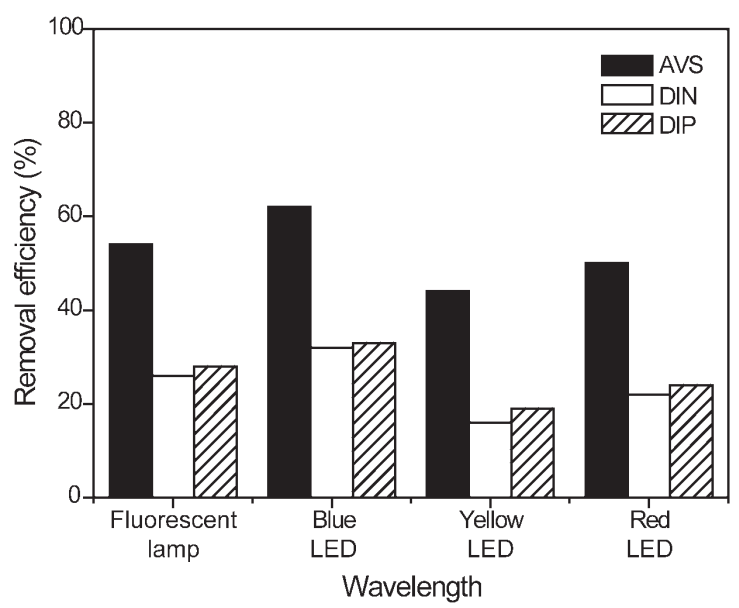

Fig. 4. The removal efficiencies of AVS, DIN and DIP under blue LED (450 nm), yellow LED (590 nm), red LED (650 nm) and fluorescent lamp (mixed wavelength). from 103 to $75 \mu \mathrm{M}$, respectively. Under blue LED, chl. $a$ increased from 0.50 to $22.22 \mathrm{mg} / \mathrm{m}^{2}$ and cell density of Nitzschia sp. increased by $4 \times 10^{4} \mathrm{cell} / \mathrm{cm}^{2}$. AVS were decreased from 15.56 to $5.86 \mathrm{mg}$ S/g-dry and, DIN and DIP decreased from 1382 to $847 \mu \mathrm{M}$ and from 118 to $80 \mu \mathrm{M}$, respectively. Under yellow LED, chl. $a$ increased from 0.26 to $8.63 \mathrm{mg} / \mathrm{m}^{2}$ and cell density of Nitzschia sp. increased by $1 \times 10^{3} \mathrm{cell} / \mathrm{cm}^{2}$. AVS decreased from 14.97 to $8.00 \mathrm{mg} \mathrm{S} / \mathrm{g}$-dry and, DIN and DIP were decreased from 1273 to $964 \mu \mathrm{M}$ and from 93 to $77 \mu \mathrm{M}$, respectively. Finally, under red LED, chl. $a$ increased from 0.34 to $13.10 \mathrm{mg} / \mathrm{m}^{2}$ and cell density of Nitzschia sp. increased by $3 \times 10^{3} \mathrm{cell} / \mathrm{cm}^{2}$. AVS decreased from 14.55 to $6.86 \mathrm{mg}$ S/g-dry and, DIN and DIP decreased from 1051 to $841 \mu \mathrm{M}$ and from 97 to $75 \mu \mathrm{M}$, respectively. The specific growth rate of Nitzschia sp. was high in the order of blue LED, fluorescent lamp, red LED, yellow LED (Table 2). In addition, the removal efficiencies for AVS, DIN and DIP were high in the order of blue LED, fluorescent lamp, red LED, yellow LED (Fig. 4).

\section{DISCUSSION}

\section{Optical characteristics on the growth of four BMA species and Alexandrium tamarense}

In microalgae, the most common responses to changes in the spectral composition of light are variations of: (1) pigment composition, (2) the ratio of lightharvesting pigments to reaction centers, (3) concentrations of the components of electron transport chains, (4) carboxylic enzyme activities (5) photosynthetic rates, (6) dark respiration rates and (7) the overall biochemical composition (Voskresenskaya, 1972; Senger, 1987). Therefore, changes in the spectral composition of light can cause important variations in growth rate and metabolism (Wallen and Geen, 1971; Flaak and Epifanio, 1978; Harrison et al., 1990; Sánchez-Saavedra and Voltolina, 1996).

The $\mu_{\max }$ of four BMA species and the harmful algae A. tamarense were highest under blue wavelength (Table 1). The main photosynthetic pigment, chlorophyll $a$, absorbs mainly light of violet-blue and red wavelengths. Blue wavelength is effectively used for photosynthesis and growth by microalgae. High growth efficiencies under blue wavelength in other marine phytoplankton have also been reported. This results is similar to that obtained for the growth of the diatoms Chaetoceros sp., Skeletonema costatum (SánchezSaavedra and Voltolina, 1996) and Thalassiosira minima (Shikata et al., 2009), the dinoflagellates Heterocapsa cicularisquama (Oh et al., 2008) and Cochlodinium polykrikoides (Oh et al., 2006) and the raphidophyte Heterosigma akashiwo (Shikata et al., 2009) were markedly stimulated under blue wavelength. Moreover, Wallen and Geen (1971) reported that chlorophyll $a$ of blue wavelength in diatom Cyclotella nana is more increased compared with that of white wavelength. Jeffrey and Vesk (1977) also reported similar results in diatom Stephanopyxis turris. This might be due to increase in DNA and RNA synthesis under 
blue wavelength (Wallen and Geen, 1971). Also, Sokawa and Hase (1967) reported that light indirectly affects cell division, because of its direct effects on DNA synthesis. Thus, growth rate of four BMA species and $A$. tamarense has stimulated more under blue wavelength than other wavelength because promotion of DNA synthesis might have been increased cell division.

Some studies reported that the growth of microalgae was optimal under exposure to red wavelength. According to these results, the growth rate of the bluegreen algae Spirulina platensis and the green algae Chlorella pyrenoidosa, and C. vulgaris were higher under red wavelength than blue wavelength (Matthijs et al., 1996; Wang et al., 2007; Yan et al., 2013). These were logical findings because green microalgae are known to be good at absorbing red light for photosynthesis through the green pigment chlorophyll (Matthijs et al., 1996). On the other hand, blue wavelength exposure was optimal for four BMA species and A. tamarense in this study. Thus, the growth of microalgae under monochromatic light might be species-specific or taxon-specific.

Yellow is not major wavelengths absorbed by chlorophyll, although some microalgae including the diatoms Hasela ostrearia, S. costatum, Chaetoceros sp. and T. minima, and the blue-green algae S. platensis are available as light sources for growth (Mouget et al., 2004; Wang et al., 2007; Shikata et al., 2009). Although these species could grow under yellow wavelength, their growth rate under yellow wavelength was lower than that under other wavelengths. In particular, the growth of the dinoflagellates Prorocentrum minimum, P. triestinum and $P$. dentatum, and the raphidophyte $H$. akashiwo was suppressed under yellow wavelength at irradiance levels less than $40 \mu \mathrm{mol} / \mathrm{m}^{2} / \mathrm{s}$ (Shikata et al., 2009). In addition, the growth of the dinoflagellate $A$. tamarense was suppressed under yellow and red wavelengths at irradiance levels less than $70 \mu \mathrm{mol} / \mathrm{m}^{2} / \mathrm{s}$. However, Oh et al. (2007) reported that BMA Nitzschia sp. could be absorb almost wavelengths ranging from $400 \mathrm{~nm}$ to $700 \mathrm{~nm}$ because the chlorophyll $a$-specific absorption coefficients were similar under all wavelengths. Moreover, Klein (1988) reported that BMA could be absorb mostly wavelengths because they have diverse photosynthetic pigments such as chlorophyll $a$, $b, \beta$-carotene, fucoxanthin, diadinoxanthin, diatoxanthin, neofucoxanthin and phaeophytin. Thus, these results indicate that yellow and red wavelengths at irradiance levels less than $70 \mu \mathrm{mol} / \mathrm{m}^{2} / \mathrm{s}$, which BMA could grow but not the harmful algae, could be important information for the phytoremediation of eutrophic coastal sediments.

\section{Laboratory study for phytoremediation of eutroph- ic coastal sediments}

To remediate eutrophic coastal sediments, BMA should be able to effectively uptake and store nutrients and produce oxygen through photosynthesis. These capabilities could not only contribute to nutrient removal from the interstitial waters, but could also promote the decomposition of organic matter and oxidation of hydrogen sulfide. In our previous study, among the four BMA species such as Achnanthes sp., Amphora sp., Navicula sp. and Nitzschia sp., Nitzschia sp. had the highest ability to uptake and store nutrients under all wavelengths (Kwon et al., 2013). Also, Nitzschia sp. produced the highest amounts of oxygen under all wavelengths in this study. Thus, Nitzschia sp. was selected for water tank experiment because of a useful species for phytoremediation .

In the sedimentary environment, pollutants flowing into coastal areas ultimately sink into the sediments. Even when the inflow of pollutants is blocked, the existing polluted coastal sediments can continue to act as a source of pollutants for the water column. In particular, if degradable substances are abundant, the pollution of the water column might be accelerated. Thus, it is important not only to eliminate pollutant inputs from terrigenous point sources and aquacultures but also to remediate contaminated sediments. The remediation of contaminated sediments observed during water tank experiments could be approached two aspects. First, there was a decrease in AVS by the photosynthetic activity of Nitzschia sp., and second, there was a decrease in inorganic nutrients such as ammonium, nitrate, and phosphate by uptake of Nitzschia sp.

In anaerobic sediments, sulfate reduction by anoxic bacteria leads to the formation of sulfides, which is called acid volatile sulfides (AVS). AVS is a natural agent in sediments which complexes some cationic metals and thereby influences the toxicity of these metals to benthic organisms. Hydrogen sulfide is formed from the dissimilatory reduction of sulfate and the decomposition of amino acids such as cysteine. Hydrogen sulfide then reacts with ferrous iron to form the amorphous FeS which comprises the majority of AVS. Benthic organisms living on or in sediments are commonly exposed to this substance, which is a pollutant of concern due to its extremely toxicity. The oxidation of AVS (e.g. $\mathrm{H}_{2} \mathrm{~S}$ and $\mathrm{FeS}$ ) can be achieved by oxidants such as $\mathrm{O}_{2}, \mathrm{NO}_{3}^{-}$, $\mathrm{MnO}_{2}$, and $\mathrm{FeOOH}$ (Aller and Rude, 1988). Thus, oxygen produced by photosynthetic processes can play an important role in the oxidation of AVS. The present results clearly showed that the NPR was high in the order of blue LED, fluorescent lamp, red LED, yellow LED. In particular, the NPR corresponds with the growth rate calculated for the four BMA species incubated under the same wavelengths. A general enhancement in photosynthetic activity was recorded when microalgae were exposed to the blue spectrum. Moreover, the highest photosynthetic activity was recorded under blue light, as already reported for some other marine microalgae (Wallen and Geen 1971; Humphrey, 1983; Vogel and Sager, 1985). These results indicate that if the growth of BMA can be stimulated using LEDs, then the produced oxygen may have promoted the oxidation of AVS.

Microalgae have a great potential for removing inorganic nutrients during environmental improvement, and they have received much attention in recent years (Kim 
et al., 2003; Pizarro et al., 2006; Khan and Yoshida, 2008). The most widely studied algal species for nitrogen and phosphorus removal are Scenedesmus (Shi et al., 2007), Chlorella (Hernandez et al., 2006) and Spirulina (Olguín, 2003). Nutrient removal by these species is effective during the wastewater treatment. As such, the removal of nitrogen and phosphorus from wastewater is a fundamental approach to preventing the eutrophication and algal bloom in coastal areas. The present results clearly show that the removal efficiency and flux of nutrients (DIN and DIP) was the highest under blue wavelength and the lowest under yellow wavelength (Table 2). These trends in nutrient removal correspond well with the growth rate of Nitzschia sp. These results indicate that if the growth of BMA can be stimulated using LEDs, then nutrient uptake by BMA may have promoted removal of nutrients.

The present results clearly show that remediation of contaminated sediments was the highest under blue wavelength and the lowest under yellow wavelength. Thus, blue wavelength should be used in the field application to maximize remediation efficiency. However, outbreaks of paralytic shellfish poisoning and A. tamarense blooms along Masan Bay have occurred annually in the spring and early summer for many years. During these seasons, the use of red wavelength under irradiance levels less than $70 \mu \mathrm{mol} / \mathrm{m}^{2} / \mathrm{s}$ may be useful because under those conditions, beneficial BMA species could grow but the harmful algae could not. In conclusion, phytoremediation aimed at the remediation of contaminated coastal sediments should use red wavelength during spring and summer, and blue wavelength during autumn and winter.

\section{ACKNOWLEDGMENTS}

This work was supported by a Research Grant of Pukyong National University (2013).

\section{REFERENCES}

Aller, R. C. and P. D. Rude 1988 Complete oxidation of solid phase sulfides by manganese and bacteria in anoxic marine sediments. Geochim. Cosmochim. Acta., 52: 751-765

Asaoka, S. and T. Yamamoto 2010 Blast furnace slag can effectively remediate coastal marine sediments affected by organic enrichment. Mar. Poll. Bull., 60: 573-578

Bragg, J. R., R. C. Prince, E. J. Harner and R. M. Atlas 1994 Effectiveness of bioremediation for the Exxon Valdez oil spill. Nature, 368: 413-418

Coates, J. D., A. R. Bruce and J. D. Haddock 1998 Anoxic bioremediation of hydrocarbons. Nature, 396: 730

Cho, H. Y., J. W. Chae and S. T. Jeong 2000 Pollutant budget change due to construction of wastewater treatment plant in Masan Bay. Kor. Soc. Coast. Ocean Eng., 12: 149-155

Doblin, M. A., S. I. Blackburn and G. M. Hallegraeff 1999 Growth and biomass stimulation of the toxic dinoflagellate Gymnodinium catenatum (Graham) by organic substances. J. Exp. Mar. Biol. Ecol., 236: 33-47

Flaak, A. R. and C. E. Epifanio 1978 Dietary protein levels and growth of the Oyster Crassostrea virginica. Mar. Biol., 15: 157-163

Guillard, R. R. L. and D. Ryther 1962 Studies of marine planktonic diatoms. I. Cyclotella nana Hustedt and Detonula con- fervacea (Cleve) Gran. Can. J. Microbiol., 8: 229-239

Harrison, P. J., P. A. Thompson and G. S. Calderwood 1990 Effects of nutrient and light limitation on the biochemical composition of phytoplankton. J. App. Phycol., 2: 45-56

Hernandez, J., L. E. de-Bashan and Y. Bashan 2006 Starvation enhances phosphorus removal from wastewater by the microalga Chlorella spp. co-immobilized with Azospirillum brasilense. Enzyme Microb. Technol., 38: 190-198

Humphrey, G. H. 1983 The effect of the spectral composition of light on the growth, pigments and photosynthetic rate of unicellular algae. J. Exp. Mar. Biol. Ecol., 66: 49-67

Jeffrey, S. W. and M. Vesk 1977 Effect of blue-green light on photosynthetic pigments and chloroplast structure in the marine diatom Stephanopyxis turris. J. Phycol., 13: 271-279

Karim, M. A., K. Fukami and A. Pater 2003 Enhancement of inorganic nutrient regeneration in a eutrophic sediment-bottom water complex system by adding effective indigenous bacteria. Fish. Sci., 69: 1146-1157

Khan, M. and N. Yoshida 2008 Effect of L-glutamic acid on the growth and ammonium removal from ammonium solution and natural wastewater by Chlorella vulgaris NTM06. Biores. Technol., 99: 575-582

Kim, S. R., S. S. Woo, E. H. Cheong and T. S. Ahn 2003 Nutrient removal from sewage by an artificial food web system composed of phytoplankton and Daphnia magna. Ecol. Eng. 21: 249-258

Klein, B. 1988 Variations of pigment content in two benthic diatoms during growth in batch cultures. J. Exp. Mar. Biol. Ecol., 115: $237-248$

Kwon, H. K., S. J. Oh and H. S. Yang 2013 Growth and uptake kinetics of nitrate and phosphate by benthic microalgae for phytoremediation of eutrophic coastal sediments. Biores. Technol., 129: 387-395

Lederman, T. C. and P. Tett 1981 Problems in modeling the photosynthesis-light relationship for phytoplankton. Bot. Mar., 24 125-134

Lee, C. W. and B. Y. Min 1990 Pollution in Masan Bay, a matter of concern in South Korea. Mar. Poll. Bull., 21: 226-229

Lovley, D. R. 2001 Anaerobes to the rescue. Science, 293: 14441446

Matthijs, H. C. P., H. Balke, U. M. Van Hes, B. M. A. Kroon, L. R. Mur and R. A. Binot 1996 Application of light-emitting diodes in bioreactors: flashing light effects and energy economy in algal culture (Chlorella pyrenoidosa). Biotech. Bioeng., 50 $98-107$

Ministry of Land, Transportation and Marine Affairs (MLTM, South Korea) 2008 Basic plan for coastal TMDL in Masan Bay, a special management area (in Korean)

Ministry of Land, Transportation and Marine Affairs (MLTM, South Korea) 2010 Standard methods for marine environmental analysis. Seoul, p. 495 (in Korean)

Mouget, J. L., P. Rosa and G. Tremblin 2004 Acclimation of Haslea ostrearia to light of different spectral qualities-confirmation of 'chromatic adaptation' in diatoms. Photochem. Photobiol. B: Biol., 75: 1-11

Murphy, T. P. and E. E. Prepas 1990 Lime treatment of hardwater lakes to reduce eutrophication. Veth. Internat. Verein Limnol., 24: 327-334

Oh, S. J., Y. H. Yoon, D. I. Kim, Y. Shimasaki, Y. Oshima and T. Honjo 2006 Effects of light quantity and quality on the growth of the harmful dinoflagellate Cochlodinium polykriokoides Margalef (Dinophyceae). Algae, 21: 311-316

Oh, S. J., D. S. Park, H. S. Yang, Y. H. Yoon and T. Honjo 2007 Bioremediation on the benthic layer in polluted inner bay by promotion of microphytobenthos growth using light emitting diode. J. Kor. Soc. Mar. Environ. Eng., 10: 93-101

Oh, S. J., D. I. Kim, T. Sajima, Y. Shimasaki, Y. Matsuyama, Y. Oshima, T. Honjo and H. S. Yang 2008. Effects of irradiance of various wavelengths from light emitting diodes on the growth of the harmful dinoflagellate Heterocapsa circularisquama and the diatom Skeletonema costatum. Fish. Sci., 74: 137145 
Olguín, E. J. 2003 Phycoremediation: key issues for cost-effective nutrient removal processes. Biotechnol. Adv., 22: 81-91

Pizarro, C., W. Mulbry, D. Blersch and P. Kangas 2006 An economic assessment of algal turf scrubber technology for treatment of dairy manure effluent. Ecol. Eng., 26: 321-327

Porter, K. G. and Y. S. Feig 1980 The use of DAPI for identifying and counting aquatic microflora. Limnol.Oceanogr., 25: 943948

Romantschuk, M., I. Sarand, T. Petänen, R. Peltola, M. JonssonVihanne, T. Koivula, K. Yrjälä and K. Haahtela 2002 Means to improve the effect of in situ bioremediation of contaminated soil: an overview of novel approaches. Environ. Poll., 107: 179-185

Sánchez-Saavedra, M. D. and D. Voltolina 1996 Effect of bluegreen light on growth rate and chemical composition of three diatoms. J. Appl. Phycol., 8: 131-137

Scor-Unesco, J. 1966 Determination of photosynthetic pigments in seawater. In "Monographs on Oceanographic Methodology 1", ed. by J. Unesco, J., Unesco publishing, Paris, pp. 11-18

Senger, H. and B. Bauer 1987 The influence of light quality on adaptation and function of the photosynthetic apparatus. Photochem. Photobiol., 45: 939-946

Shi, J., B. Podola and M. Melkonian 2007 Removal of nitrogen and phosphorus from wastewater using microalgae immobilized on twin layers: an experimental study. J. Appl. Phycol., 19: 417423

Shikata, T., A. Nukata, S. Yoshikawa, T. Matsubara, Y. Yamasaki, Y. Shimasaki, Y. Oshima and T. Honjo 2009 Effects of light quality on initiation and development of meroplanktonic diatom blooms in a eutrophic shallow sea. Mar. Biol., 156: 875-889

Sokawa, Y. and E. Hase 1967 Effects of light on the deoxyribonucleic acid formation and cellular division in Chlorella protothecoides. Plant and Cell Physiol., 8: 509-522

Steele, J. H 1962 Environmental control of photosynthesis in sea. Limnol. Oceanogr., 17: 137-150

Strickland, J. D. H. and T. R. Parsons 1972 A practical handbook of seawater analysis, $2^{\text {nd }}$ ed. Bulletin of Fisheries Research Board of Canada, Canada, p. 310

Suresh, B. and G. A. Ravishankar 2004 Phytoremediation-a novel and promising approach for environmental clean-up. Crit. Rev. Biotechnol., 24: 97-124
Suzuki, Y., S. D. Kelly, K. M. Kemner and J. F. Banfield 2002 Radionuclide contamination: nanometre-size products of uranium bioreduction. Nature, 419: 134

Vogel, H. and J. C. Sager 1985 Photosynthetic response of Prorocentrum mariae-lebouriae (Dinophyceae) to different spectral qualities, irradiances, and temperatures. Hydrobiologia, 128: 143-153

Voskresenskaya, N. P. 1972 Blue light and carbon metabolism Annu. Rev. Plant. Physiol. Plant. Mol. Biol., 23: 219-234

Wallen, D. G. and G. H. Geen 1971 Light quality in relation to growth, photosynthetic rates and carbon metabolism in two species of marine plankton algae. Mar. Biol., 10: 34-43

Wang, C. Y., C. C. Fu and Y. C. Liu 2007 Effects of using lightemitting diodes on the cultivation of Spirulina platenesis. Biochem. Eng. J., 37: 21-25

Winker, L. W. 1888 Die Bestimmung des im Wasser gelösten Sauerstoffen. Ber. Dtsche. Chem. Ges., 21: 2843-2855

Wolfe, D. A., M. M. Krahn, E. Casillas, S. Sol, T. A. Thompson, J. Lunz and K. J. Scott 1996 Toxicity of intertidal and subtidal sediments contained by the Exxon Valdez spill. In "Proceedings of the Symposium Exxon Valdez Oil Spill. 18. American Fisheries Society Symposium" ed. by S. D. Rice, R. B. Spies, D. A. Wolfe and B. W. Wright, Bethesda, MD, pp. 121-139

Wynne, D. and G. Y. Rhee 1986 Effects of light intensity and quality on the relative $\mathrm{N}$ and $\mathrm{P}$ requirement (the optimum $\mathrm{N}: \mathrm{P}$ ratio) of marine planktonic algae. J. Plankton Res., 8: 91-103

Yamamoto, T., I. Goto, O. Kawaguchi, K. Minagawa, E. Ariyoshi and O. Matsuda 2008 Phytoremediation of shallow organically enriched marine sediments using benthic microalgae. Mar. Pollut. Bull., 57: 108-115

Yan, C., X. Luo and Z. Zheng 2013 Effects of various LED light qualities and light intensity supply strategies on purification of slurry from anaerobic digestion process by Chlorella vulgaris. Inter. Biodeterio. Biodegrada. 79: 81-87

Yim, U. H., S. H. Hong, W. J. Shim, J. R. Oh and M. Chang 2005 Spatio-temporal distribution and characteristics of PAHs in sediments from Masan Bay, Korea. Mar. Pollu. Bull., 50: 319326

Yoo, K. I. 1991 Population dynamics of dinoflagellate community in Masan Bay with a note on the impact of environmental parameters. Mar. Poll. Bull., 23: 185-188 